\title{
A BOOK REVIEW OF CENTRAL BANK POLICY THEORY AND PRACTICE BY PERRY WARJIYO AND SOLIKIN M. JUHRO
}

\author{
Hal Hill
}

Australian National University, Australia. Email: hal.hill@anu.edu.au

The volume under review is a most welcome addition to the still relatively slim collection of economics volumes written in English by Indonesian scholars. There is an established tradition of senior Indonesian policy makers writing major scholarly volumes in their fields of expertise before or after holding high office. One thinks for example of Widjojo Nitisastro's Population Trends in Indonesia (1970), Radius Prawiro's Indonesia's Struggle for Economic Development: Pragmatism in Action (1998), and Soedradjad Djiwandono's Bank Indonesia and the Crisis: An Insider's View (2005), among several others. (It is noteworthy that two of these authors were also Bank Indonesia governors.) In an earlier era, Professor Sumitro Djojohadikusumo was the trailblazer, combining serious scholarship along with high policy responsibilities. It is testimony to Indonesia's political leaders and governance tradition over several decades that policy leadership and serious scholarship have been able to comfortably and productively co-exist.

This encyclopaedic volume, intended to bridge the gap between the academic and policy worlds, is written in this tradition. Except that the authors are still in government, respectively as Governor of Bank Indonesia, and Head of its Bank Indonesia Institute. Dr Warjiyo and Dr Solikin have somehow found time to write a book on central banking that is destined to become the standard reference on the subject for policy makers and academics in Indonesia. To convey a sense of the scale and scope of the undertaking, the volume comprises 15 chapters, 585 pages, 39 figures and 33 tables. It is well referenced, with the relevant central banking and monetary policy literature surveyed and integrated, as indicated by its 35 pages of references.

The volume consists of five main sections: a general review, monetary policy and economy, monetary policy framework, institutional aspects of central bank policy, and new paradigm of central bank policy. The earlier chapters establish the standard theoretical frameworks and are to some extent chronological. These lead the reader towards some major contemporary policy and analytical issues, particularly the three chapters in the final 'new paradigms' section. Each chapter includes clear and non-technical introductions and conclusions. As would be expected, several chapters require that the reader has at least intermediate-level mathematics, but the accompanying intuition is also provided. The authors explain in the Preface that the volume grew out of their experience teaching graduate-level international monetary and financial economics at the University of Indonesia, and this experience no doubt enhances the reader-friendly aspects of the volume. An attractive feature of the volume is the explicit attention given to Indonesia. The majority of chapters have a concluding section on the relevance of the material for Indonesia. There is also one chapter devoted exclusively to Indonesia, chapter 9 on inflation targetting. We return to this chapter below. 
The two chapters in section I set the scene. The authors draw attention to the salient features of modern central banking: central bankers are constantly under the spotlight, their every utterance dissected by the financial markets, in the context of rising global capital flow volatility. Moreover, the global financial crisis (GFC) 'turned central bank practices on their head' (p.7), as the era of low inflation led to strong credit growth, asset price bubbles, and high financial leverage. In surveying the evolution of central banking over the centuries, the authors argue that there are four key lessons learnt: central banks play an essential role in supporting economic growth; central banks need jurisdiction over monetary policy, the payments system, and macroprudential regulation and supervision; central banks need to be given autonomy to pursue its mandated goals; and this autonomy has to be accompanied by institutional arrangements that provide public accountability and transparency.

Section II dives into the theory of central banking and the economy. Chapter 3 commences with monetary theory in a closed economy, from classical theory to Keynesian theory, IS-LM curves and the Phillips Curve. It then moves on to the 'new paradigms' developed by Joseph Stiglitz and others, including the monetary analysis of the quantity of credit, rather than money. The latter proposition leads to the conclusion that monetary policy operating through interest rates needs to be strengthened by macroprudential policy, particularly banking regulations that directly affect credit. Chapter 4 on exchange rates and the economy extends the discussion to monetary theory in an open economy, centred around the monetary policy trilemma in an open economy, Mundell-Fleming, Dornbusch's overshooting and related literature. In chapter 5, the monetary policy transmission mechanism, the analysis is on how monetary policy affects the financial system and the economy. The authors here return to one of their key messages, that monetary policy based on interest rates and exchange rates must be supported by macroprudential policies that manage credit growth.

In section III the authors switch focus to the monetary policy framework, and in particular central bank policy making theories and practices. These include the monetary policy strategic framework in chapter 6, much of it focusing on how to manage the 'duality' issue, of both output stability and price stability, and chapter 7 on the monetary policy operational framework. The latter includes a wide-ranging discussion of targets, rules versus discretionary policy making, and how to handle shocks emanating from both the demand and supply sides. Two chapters on the inflation targetting framework (ITF) complete this section, the first examining various ITF regimes, and common misconceptions surrounding them, and the second the implementation of the ITF in Indonesia.

Having canvassed monetary policy theory and implementation, the authors elucidate the institutional aspects of central bank policy in section IV, focusing on institutional theories and practices that underpin the principles of good governance for central bank policy. Three main issues are examined, each one receiving chapter-length treatment. The first is the importance of credibility, which in turn dictates that, as much as possible, central banks should follow rules (for example, the Taylor Rule) over discretion. Nevertheless, as the authors also point out, defining and achieving credibility are no small matters. Next, in chapter 10, are the interrelated issues of central bank independence and accountability. A cornerstone of this objective is the delegation of authority to a conservative central bank, sometimes referred to as the 'Rogoff model'. But what exactly is delegated - goals, 
instruments, other variables? And how is accountability defined and assessed? These important issues are investigated in this chapter. The final element of this institutional framework is policy transparency and communications strategy. In an age of global financial integration both are essential; in passing, no doubt based on first-hand experience, the authors note the more so as 'democracy flourishes'.

The volume concludes with three chapters on 'new paradigms of central bank policy'. This brings the reader right up to contemporary policy issues and debates and will therefore be of most interest to policy makers. The focus is on the latest perspectives and new paradigms for central banks in the wake of the GFC. The authors return to topics that are clearly in the forefront of central bank thinking, including the management of foreign capital flows, macroprudential policy, payment systems policy, and the challenge of achieving the dual mandate of price and exchange rate stability, as well as financial system stability. The first facet in chapter 13 is back to the policy trilemma, that is, how to conduct monetary policy in the context of often volatile foreign capital flows, especially since the GFC. The authors argue for a 'two target approach using two instruments', that is, a monetary policy based on interest rates, supplemented by foreign exchange intervention and foreign capital flow management. The next chapter investigates macroprudential policy and financial system stability. The starting point is the costly lessons of the GFC and the dangers of financial sector 'procyclicality', leading to asset bubbles and other problems. There is also the danger of contagion, resulting from the growing interconnectedness and networking of the financial sector. The key conclusion is the importance of coordinating microprudential, macroprudential, and macroeconomic (monetary and fiscal) policies. An informative Figure 14.1 illustrates this framework.

A long and occasionally technical chapter 15 on the central bank policy mix completes the volume and pulls together the key strands. In the authors' words, this mix '... represents the optimal integration of monetary policy, macroprudential policy, and foreign capital flow management, as applied by the central bank to achieve price stability and maintain financial system stability.' (p.463) Here also, the framework is illustrated graphically, in Figure 15.1. About one-quarter of the chapter is devoted to the Indonesian experience with this policy approach.

As noted, an attractive feature of the volume is the extensive coverage of Indonesia. Most of the chapters have a concluding section on the Indonesian experience, as it relates to the theoretical, empirical and policy material presented in that chapter. There is also extensive reference to the Indonesian literature on the subject matter, most of it drawing on Bank Indonesia material. The Indonesian references commence quite early in the volume. We are reminded that 'Indonesia's bitter experience during the 1960s showed that using monetary policy to finance lighthouse projects created hyperinflation.' (p.49) On p.111, with great understatement, the authors observe of the historic, indeed momentous, decision to let the Rupiah float (on August 14, 1997) that 'the new exchange rate system was introduced in response to government policy to confront speculative attacks in the foreign exchange markets ...' On pp.151-7 there is a technical discussion surveying the literature on monetary policy transmission in Indonesia. On p.190 we get a hint at the possibility of looming difficulties in the wake of the largely successful but incomplete 1980s economic liberalizations when the authors note that the magnitude and mobility of foreign funds [in the wake of the liberalizations] also complicated monetary policy implementation by BI'. 
For anybody interested in Indonesian macroeconomic policy chapter 9 on the implementation of the Inflation Targetting Framework in Indonesia warrants serious attention. It follows the preceding chapter on the theory of ITF and international experiences. The story commences with the Bank Indonesia Act (number 23, 1999), enacted under the important but short-lived Habibie Presidency, and while Indonesia was still formally under the IMF program.

For this reviewer, it is the most interesting chapter of the volume, as it alludes to the struggle to implement monetary policy autonomy and inflation targetting in the early transitional years of Indonesian democracy. (It is worth remembering that Indonesia had five presidents in just six years from 1998 to 2004.) The authors write candidly of this experience: 'The path to full ITF implementation in Indonesia was fraught with difficulties.' (p.262) Inflation was influenced by factors outside the immediate control of monetary policy. The government, members of the parliament (DPR) and the general public had to be educated about the new framework. There was still extensive corporate and personal hardship, and considerable hostility towards the IMF. The collapse of much of the modern banking sector and the value of the Rupiah was a very recent memory. The country had also experienced serious inflationary problems in 1998.

Table 9.1, 'Actual and Target Inflation' for the years 2005-15, sets out the results. This table includes columns on the inflation target, actual inflation, core inflation, the SBI rate, and contextual notes. For example, in 2005 the inflation target was $5-7 \%$ while actual inflation was $17.1 \%$. The explanatory note refers to global shocks and fuel price hikes, the latter the result of government efforts to reduce the burgeoning fuel subsidies. But in successive years the gap between targeted and actual inflation generally narrowed, again excepting years of high fuel prices and other shocks, and Bank Indonesia's targeted rate was gradually lowered. Bank Indonesia's technical modelling capabilities also progressed. The authors adopt a cautionary concluding note, but clearly this is a case of policy success in sometimes challenging conditions.

There is further discussion of Indonesia in subsequent chapters. For example, in discussing monetary policy credibility it is emphasized (pp.311-314) that the process of reducing inflation (and inflationary expectations) in the early 2000's was necessarily a gradual one since 'monetary policy ... is not fully credible, thus the learning process of economic agents ... was slightly more protracted'. In other words, this did not resemble Indonesia's 'big bang' stabilization of the late 1960s, a very different era. In addition, Bank Indonesia has to manage other inflationary elements, including administered prices (for example changes in fuel subsidies) and volatile prices, mainly food staples. The authors stress that there is also a learning process for Bank Indonesia, as it 'must increase monetary policy communications ... to help gradually lower and anchor public inflation expectations ...' (p.317) Furthermore, the era of independence and accountability required a cultural change within the Bank, 'from an inward-looking organization to becoming an outward-looking organization.' (p. 382)

This is not a 'tell-all' book on the inner workings and the occasional policy dramas behind the scenes of Indonesian central banking. Nor can it be, of course, since the authors are still serving government officials. For example, the Asian Financial Crisis and its immediate aftermath was a traumatic period for the Bank, and Indonesian economic policy makers more generally. It is one thing to be granted autonomy, but inevitably the path to full operational autonomy was not 
an easy one, as illustrated by the fact that from the late 1990s three successive Bank Indonesia governors were either dismissed or placed under arrest. Moreover, the cordial relationship between the International Monetary Fund and key Indonesian economic policy agencies like Bank Indonesia was severely tested. It would be interesting to know more about the debates within Bank Indonesia, and between it and the three presidents in the early democratic era. (The experience of Bank Indonesia during the AFC was in any case discussed extensively in the Soedradjad volume referred to above.)

There are numerous other issues on which the reader would be interested to learn from the authors. These include the one banking rescue in the democratic era, that of Bank Century, a relatively minor bank, the prompt and effective rescue of which had broader political implications. One wonders also whether the authors have views on the institutional separation of monetary policy and financial supervision responsibilities, resulting in the establishment of the Financial Services Authority (the OJK) in 2011. There is also the evolving relationship between Bank Indonesia and the Ministry of Finance, as the former transition to independence and the latter commenced operations under the 2003 Fiscal Law. Yet another policy issue that comes to mind is how far the government should pursue its de facto policy - controversial in some quarters - of in effect targetting (and limiting) the current account deficit. Then there is Indonesia's management of the 2013 Taper Tantrum episode, on which we already have something of an insider's view, at least from the Ministry of Finance, in M. Chatib Basri's 'India and Indonesia: Lessons Learned from the 2013 Taper Tantrum' (Bulletin of Indonesian Economic Studies, 53 (2), 2017).

These and many other issues can be for retirement, when the authors come to write their memoirs. Such a volume could then join the ranks of memoirs by other retired central bank governors, such as Ben Bernanke's The Courage to Act. A Memoir of a Crisis and its Aftermath (2015), and Mervyn King's The End of Alchemy. Money, Banking and the Future of the Global Economy (2016).

In passing central bankers' memoirs may, and generally do, range from the technically serious to the informative light-hearted. This reviewer's favourite example of the latter genre in fact comes from Indonesia. Radius Prawiro, Governor of Bank Indonesia from 1966 to 1973, in the volume referred to above included an aside that in the late 1960s he was always one of the best-informed people in Indonesia for the simple reason that he had one of the very few air conditioned offices in the country, and therefore friends would drop by to say hello and cool off!

This English-language volume puts Indonesia on the global policy and intellectual map, as a serious player in the international community of central bankers. A Bahasa Indonesia edition has already been released as Kebijakan Bank Sentral. Teori dan Praktik (see http://www.rajagrafindo.co.id/produk/kebijakanbank-sentral-teori-dan-praktik-soft-cover/). Meanwhile, the current and coming generations of Indonesian university students, economics officials and policy makers will benefit greatly from this volume. It really matters to have economically literate academic and policy communities, and this is the volume for them to learn the fundamentals of monetary policy and banking. 
This page is intentionally left blank 